\title{
A CONCEPTUAL FRAMEWORK OF INTEGRITY
}

\author{
ANTONI BARNARD \\ Department of Industrial and Organisational Psychology \\ UNISA \\ South Africa \\ WILLEM SCHURINK \\ Department of Human Resource Management \\ University of Johannesburg \\ South Africa \\ MARIÈ DE BEER \\ Department of Industrial and Organisational Psychology \\ UNISA \\ South Africa \\ Correspondence to: Antoni Barnard \\ e-mail: barnaha@unisa.ac.za
}

\begin{abstract}
This article reports on the findings of a qualitative study in which the construction of integrity of some business leaders was explored. Data were gathered through ten in-depth interviews with six South African business leaders commended to be champions of integrity. A grounded-theory approach to the data analysis elicited five themes. These themes and their interrelatedness are discussed in this article and a conceptual framework of integrity is proposed. Integrity is conceptualised as a multifaceted and dynamic construct based on a moral foundation and inner drive that is managed by cognitive and affective processes manifesting various integrity-related behaviours.
\end{abstract}

Keywords: integrity, integrity assessment, qualitative research, grounded theory, business ethics

Integrity as a psychological construct impacting on workplace behaviour is receiving a considerable amount of attention in various industrial and organisational psychology domains, such as leadership, organisational dynamics, employee wellness and employee selection. More specifically, it has been found to be a central trait of effective leaders (Craig \& Gustafson, 1998; Petrick \& Quinn, 1997), a principal determinant of trust in organisations (Becker, 1998), a component of employee wellness (Harter, 2002; Schabracq, 2003), an essential component of productive work relationships (Cameron, 2003) and a fairly valid predictor of job performance and counterproductive behaviour (Ones, Viswesvaran \& Schmidt, 1993). It has furthermore been noted as one of the constructs in positive psychology (Cameron, 2003; Park \& Peterson, 2003; Peterson \& Seligman, 2004; Schabracq, 2003).

Primary limitations of and critique against criterion studies on integrity and work performance pertain to the construct validity of the integrity measures used in these studies (Cullen $\&$ Sackett, 2004). From the research conducted and the literature produced in the past two decades, it is evident that the issue of construct clarification with regard to integrity remains complex. Despite important research insights into integrity in the workplace, many seem to agree that the construct remains either too broad or too vague and ill-defined (Becker, 1998; Rieke \& Guastello, 1995). According to Cullen and Sackett (2004), measures of integrity have been developed on the basis of a variety of extremely multifaceted conceptualisations of the construct, reflecting a mixture of personality characteristics, attitudes and values.

Camara and Schneider (1994) attribute the concern about a valid conceptualisation of integrity to the fact that the construct has been increasingly broadened to the extent that it is now a composite of three of the constructs underlying the Big Five model of personality. Strong correlations between integrity and conscientiousness had initially been found (Hogan \& Ones, 1997; Ones, 1993). Follow-up correlation studies by Ones and Viswesvaran (2001) again reported conscientiousness to have the strongest correlation with integrity but they also indicated significant correlations with agreeableness and emotional stability. Becker (1998), however, severely criticises the tendency to equate integrity with both conscientiousness and honesty. He recognises the interrelationships between these concepts but he claims that integrity is conceptually distinct from both conscientiousness and honesty and that it therefore merits individual attention.

In the positive-psychology domain, integrity has also been linked to positive personality constructs, such as courage, care, authenticity and honesty (Harter, 2002; Park \& Peterson, 2003; Peterson \& Seligman, 2004). In philosophy and general psychology, however, integrity is, as opposed to such a construct-orientated perspective, conceptualised from a developmental perspective (Beebe, 1992; Burleson, 2001; Craig \& Gustafson, 1998; Josselson, 2000; Rosen \& Crouse, 2000; Young-Eisendrath \& Miller, 2000). Integrity conceptualisations held forth in this field can be related to the positive psychology constructs mentioned, especially with regard to authenticity (McFall, 1987; Schauber, 1996) and to wholeness (Beebe, 1992; Rosen \& Crouse, 2000).

In light of the variety of perspectives on integrity as a construct, we agree with Murphy (2000), who insists on an improved construct clarification of integrity, especially because of the immense impact of integrity on employment decisions in the organisational context. Further to the issue of construct clarification in general, South African research related to the construct clarification of integrity seems to be very limited.

\section{Objective of the study}

The objective of this research was to explore the constructions of integrity of a small number of South African business leaders in a work context and consequently to develop a conceptual framework (Miles \& Huberman, 1994; Mouton, 2002; Silverman, 2000) of integrity. The aim of this article is therefore to establish a general conceptual framework that could serve to conceptualise 
integrity and its underlying constructs as a basis for the further development of theory.

\section{RESEARCH DESIGN}

\section{Research approach}

Barrett (2003) makes it abundantly clear that sole reliance on the quantitative structuring of a psychological variable may limit the knowledge and theory-generating claims that can be made. Implicit in his argument is the fact that such sole reliance on psychometrics and measurement may exclude explicit theory on the true psychological meaning underlying the variable of study. Poor construct clarification inevitably leads to poorly designed and constructed frameworks, typologies and theories (Mouton \& Marais, 1996). Reflecting on the issue of construct clarification with regard to integrity highlighted earlier, the argument by Barrett (2003) may ring true and a shift in focus may be called for - that is, a qualitative approach to studying integrity in the work context.

A qualitative-research approach was therefore deemed most efficient in resolving the preceding research objective. Qualitative research provides access to and an understanding of people's subjective experiences of a psychological phenomenon (Camic, Rhodes \& Yardley, 2003), such as integrity. Such approach also aligns with the study's explanatory purpose, namely to develop a conceptual framework for understanding and working with integrity. According to Mouton (2002), a conceptual framework provides a systematic representation of a research phenomenon (in this case, integrity) by explicating relationships, patterns and regularities within the phenomenon. It is explanatory because it defines and explains the phenomenon being studied (Silverman, 2000).

\section{Epistemological notions}

Assuming a constructivist epistemology (Crotty, 2005) and consistent with ontological assumptions underlying critical realism (Snape \& Spencer, 2004), integrity is studied as a real behavioural phenomenon that becomes meaningful as a result of people's understanding of and experience with it. From such a constructionist perspective, not only is integrity subjectively experienced but it also manifests in socially and contextually defined and accepted conventions that facilitate the way in which people in the workplace construct the phenomenon. Despite postpositivistic ontological and epistemological notions reflecting a predominantly interpretive approach in this research, philosophical assumptions about theory, reality, theory development and knowledge creation, which fluctuate between positivism, postpositivism and postmodernism, are also evident in this study. This closely resembles the era of the "blurred genres" recognised by Denzin and Lincoln (1994; 2000) in their analysis of the periods through which qualitative research has developed. In conclusion, where qualitative research is the overall research approach of this study, the interpretivist stance followed portrays its distinctive theoretical perspective (Crotty, 2005).

\section{Research methodology}

\section{Constructivist-grounded theory methodology}

Due to this interpretivist orientation, a constructivist-grounded theory methodology (Charmaz, 2000; Mills, Bonner \& Francis, 2006) was chosen as best suited to achieving the stated purposes of this research. Crotty (2005), Charmaz (2003), Kelly (2004) and Maree, Joubert and Prinsloo (1996) regard grounded theory as a highly effective methodology in exploratory and descriptive interpretivist research. As stated above, this research purpose is also, however, explanatory. This relates to the primary purpose of grounded theory, namely the discovery or generation of a substantive theory (Glaser \& Strauss, 1967). Constructivist-grounded theory particularly emphasises the subjective interrelationship between researcher and research participants, resulting in theoretical products that are based on their co-construction of meaning (Mills et al., 2006).

\section{Research participants}

The study was initially directed by purposeful sampling (Miles \& Huberman, 1994) in seeking participants who could contribute to the understanding of integrity in the workplace. In the spirit of grounded-theory methodology, the sampling strategy followed was flexible and iterative (Marshall \& Rossman, 1995; Pidgeon \& Henwood, 1997) and was based on the guiding principles of theoretical sampling (Strauss \& Corbin, 1990).

In purposefully selecting information-rich research participants, sampling was particularly directed by selecting exemplary cases (Plummer, 2001; Yin, 2003) (cf. reputational sampling [Miles \& Huberman, 1994]). The participants were thus selected on the strength of recommendations by key informants indicating the people to be information-rich and reputable with regard to the phenomenon being studied (Ostrander, 1995; Thomas, 1995).

In total, six participants were selected with the following in common: (1) They could all be described as business elites (Hertz \& Imber, 1995) or corporate elites (Thomas, 1995) because they all had senior and executive level positions in highly successful businesses in the South African work context. (2) They had all been referred to the study as champions of integrity in their work relationships and business dealings.

\section{Data gathering}

In-depth interviewing as a type of semistructured or unstructured interviewing technique(Fontana \& Frey, 1994) was utilised, as it is ideally suited to a grounded-theory approach (Charmaz, 2003; Harkess \& Warren, 1993; Potter \& Hepburn, 2005; Rubin \& Rubin, 1995) and true to the epistemological notions in interpretivist research (Kvale, 1996).

Theoretical sampling both directs data collection and is directed by data collection to the point of data saturation (Strauss \& Corbin, 1990) or to the point of sampling to redundancy (Durrheim, 2004). In this regard, four follow-up interviews concluded a total of ten interviews with the six research participants. After the fourth follow-up interview, data indicated a point of theoretical saturation.

\section{Data capture and storage}

The interviews were tape-recorded with both a digital recorder and a cassette recorder (Plummer, 2001; Rubin \& Rubin, 1995). They were then transcribed by a professional transcriber and the transcriptions were reviewed by the researcher with due consideration of transcription pitfalls and conventions according to Easton, McComish and Greenberg (2000) and Lapadat and Lindsay (1999). The transcriptions were imported as primary documents into ATLAS.ti, which ensures secure and logically structured data storage as well as immediate search and retrieval functions (Coffey, Holbrook \& Atkinson, 1999; Henning, Van Rensburg \& Smit, 2004; Smit, 2005).

The data were substantiated by field notes compiled according to the strategies suggested by Wolfinger (2002). A reflexive journal was also kept throughout the data-gathering and dataanalysis process (Bryman \& Burgess, 1999; Kelly, 2004).

\section{Data analysis}

The data were analysed according to the original Glaser and Strauss (1967) grounded-theory analysis by ascribing meaning to the data through the method of constant comparison (Locke, 2001). The analytical process evolved through four interpretative stages of working with the data: generating, integrating and delimiting categories, and writing the final theoretical framework (Glaser \& Strauss, 1967). Strategies of analysis suggested by Locke (2001), such as "naming", "comparing" and "memoing", were used through all four stages of analysis. 
ATLAS.ti, being particularly functional in grounded-theory analysis (Coffey et al, 1999; Henning et al, 2004; Muhr, 1997) was used to analyse the data on both a textual and a conceptual level (Pandit in Henning et al., 2004).

The data were analysed iteratively and the analysis was facilitated through the principle of theoretical sensitivity. The following steps present the actual strategies employed during the data analysis:

1. The researcher immersed herself in the data by repetitively listening to the taped interviews and reviewing the transcriptions. Although she ultimately did this with all ten interviews, she started the data-analysis process by initially focusing on the first three interviews.

2. After thorough familiarisation with each interview transcription, it was imported into ATLAS.ti as a primarydocument data set. Each interview was thus managed as a separate primary document in ATLAS.ti because not all the interviews were completed at the start of the data analysis. The initial separation of interviews also made the data more manageable and facilitated more efficient comparisons within and across interviews.

3. In accordance with the conventional line-by-line analysis of the first phase in grounded-theory data analysis, a myriad of codes was generated and named from the first data sets.

4. Through iteratively adding the other interviews, the code list was refined through comparison between and among the data incidents and drafted codes. The process of refining the code list entailed the identification of new codes as data sets were added, the integration of codes with similar meaning and the distinction of redundant codes from pertinent ones through the comparison of the data incidents and codes with the research question.

5. From the start of the grounded-theory analysis, explanatory notes and memos were made, which aided in the conceptualisation of categories from the code list. Conceptual categories were thus developed on an increasing level of abstraction as data sets were added and as the data-analysis process evolved from the first phase to the second and third.

6. As part of the second phase of the analysis, the conceptual codes or categories were compared with one another to identify and clarify interrelationships. The conceptual categories were also compared with existing literature related to integrity in order to aid in the grouping together of interrelated categories. Graphic memoing as well as the creation of code-families and networks in ATLAS.ti were undertaken, which facilitated the further conceptualisation of categories and the organisation of groups of related categories.

7. With the objective of delimiting categories in the third phase of the analysis, the groups of categories were compared with one another, with existing literature and again with the original data sets, memos and field notes. Groups of categories were then conceptualised on yet a higher level of abstraction, which ultimately resulted in the identification and conceptualisation of five core themes as a presentation of the construction of integrity in the South African workplace.

8. The themes were then conceptually and theoretically explicated in detail and in relation to specific data incidents to conceptualise the main storyline analytically. The analytical story includes the specification of the nature and scope of interrelationships between themes and their relevant categories.

\section{Assurance of quality and ethical research}

Following the advice of Kelly (2004), the research was subjected to a panel peer review during its planning phase. During the review, the methodology and specific strategies of the data gathering, capture, storage and analysis were explained in detail and care was taken to show methodological and epistemological congruence in the presentation of the research design (Suddaby, 2006). To ensure rigour, trustworthiness and authenticity, themes are discussed as they are grounded in the data; verbatim extracts from the interviews are thus included in the discussion of the themes (Pidgeon \& Henwood, 1997). The research findings were later also subjected to a panel peer review. Ethical issues of confidentiality, of informed consent and of the transparency of findings were adhered to through the anonymous reporting of the data, through the thorough debriefing of the research participants before, during and after the interviews and through member checks (Leininger, 1994).

\section{RESULTS}

The large amount of rich data that was generated by the research participants was grouped into categories, subcategories and themes ${ }^{1}$. According to Locke (2001), the theoretical density of a category (or theme) is directly related to the number of properties (categories or subcategories) that describe that category or theme. The five themes that resulted from the data analysis, together with their related categories and subcategories, are therefore discussed and the way in which the categories and subcategories are clustered around the themes is depicted in Table 1 . The groundedness or theoretical density of themes is a prerequisite for the validity of qualitative data (Dey, 1999; Terre Blanche \& Kelly, 2004). The scope of this article, however, limits the explication of themes and therefore includes only the most relevant and illuminating verbatim evidence in the data.

\section{Foundational drives of integrity}

The two most prominent categories derived from the data are the moral compass and the inner drive. These categories were clustered around the theme of foundational drives of integrity.

\section{Moral compass}

One of the dominant perspectives on integrity held forth by the research participants relates integrity to a life based on moral values and principles. Integrity is defined as "are you going to stay in your values whatever those are 2", as "to do things in a particular way, according to certain norms and values" and as "moral values I guess and acting on those moral values". One research participant's account in particular summarises the view that integrity is based on living a morally principled life: "For me integrity it's all about principles really and all about morals and values it's a whole set of things that govern how you do things and do them within whether it's morally legally or otherwise correct and that's how I would in a nutshell look at integrity."

From the data, it was clear that integrity entails an internalised set of values and principles that function as the norms and standards that one lives by and that direct all one's actions and decisions. Such a view of integrity relates closely to the concept by Lennick and Kiel (2005) of a moral compass. They conceptualise every person's set of personal and internalised beliefs, values and principles as constituting their moral compass. The notion that integrity is based on a core set of values and principles or (to borrow the concept from Lennick and Kiel [2005]) on an internalised moral compass is echoed

\footnotetext{
${ }^{1}$ Although the use of the term "theme" is not frequently found in grounded-theory work, it is used here to simplify the distinction between themes and categories. Such a distinction is related to that noted by Terre Blanche and Kelly (2004) and presents a cluster of related categories under a theme.

2 Based on the concern by Easton, McComish and Greenberg (2000) about the use of punctuation in transcriptions, none was used here in order to guard adding unnecessary layers of meaning to the text, an issue also discussed by Wolfinger (2002).

${ }^{3}$ For the purposes of this article, all Afrikaans excerpts from the interview data were translated into English to aid non-Afrikaans speaking readers' understanding of the text. Due to the limited scope of an article, only the English version of an excerpt is given here.
} 
in various other perspectives on integrity (Becker, 1998; Craig \& Gustafson, 1998; Mason, 2000; McFall, 1987; Olson, 2002; Putman, 1996).

The moral compass is thus defined as having and living according to a core set of values and principles. Integrity is ultimately determined by the contextual nature of the moral compass and behaviour with integrity is driven by one's willingness to act according to the internalised values, beliefs, norms and principles that constitute one's moral compass.

The question evolved of whether integrity relates to a moral compass consisting of a unique, individualised set of values and principles or whether it relates to universal principles constituting a minimum requirement for integrity. This question is similar to one posed by Mason (2001). From the data, it was found that integrity reflects both core values and universally accepted principles. Although the research participants were hesitant to judge others with different values, they did emphasise that certain core values and principles reflect integrity and that these are shared by all people with integrity, regardless of religion or culture. Confirming this finding in the data, a variety of scholarly views strongly speaks against moral relativism (Locke \& Becker, 1998; Mason, 2001), some emphasising a set of values and principles generally deemed significant by all as the key to integrity (Becker, 1998; Cox, Lacaze \& Levine, 1999; Lickona, 2001; McFall, 1987). From an analysis of the similarities across the conventions of integrityrelated values and principles of the research participants, the following value categories were identified as fundamental to integrity (see Table 2 for an explication of these values from the raw data):

- A people orientation based on the principles of respect and empathy

- The will to live a meaningful and purposeful life

- A disposition to life based on an internal locus of control

- An approach to life facilitated by optimism and enthusiasm
Inner drive

The research participants' narratives showed another very prominent perspective clearly linking integrity to one's inner needs, aspirations, wants and goals, conceptualised in this research as the inner drive. The relevance of the inner drive to integrity seems twofold. Firstly, there seems to be a positive link between integrity and inner drive: "I think there's a relationship between people with integrity and people who fail in life. Integrity must have something to do with drive." One's inner wants, needs and aspirations thus constitute the motivational forces for achievement, progress and hard work that underlie integrity.

Secondly, however, the research participants provided examples of how one's personal needs and aspirations tempt one to act in ways that do not speak of integrity but to act in a selfish and self-seeking manner. People with a poor sense of integrity are described as those who "serve their own personal interests . . . it's about personal gain ... whether it's in terms of enriching or whatever . . . I look at how I could manipulate the situation for self-interest . . . because within that situation I've already seen the scope you know for me to be able to manipulate certain things to my own benefit or for self-interest". The inner drive therefore also contains the motive to act without integrity and to act purely for self-gain.

Integrity is thus driven by personal motives and ideals contained in the inner drive as much as it is driven by one's moral compass (one's values and principles). Personal gain achieved in a manner that does not reflect the consideration of the universal values incorporated in the moral compass provides evidence of limited integrity. Some needs generally experienced as part of the inner drive, which frequently overpower one's values and principles and entice one to act in a selfish manner, were identified from the data. These include the need for survival, the need to win, the need for power, for authority and for status and, finally, the need for wealth and success. These needs are comparable with those mentioned by Furnham and Taylor (2004), Warren (2002) and Harter (2002) in their discussions about people who act without integrity.

TABLE 1

Grouping of categories into five core themes

\begin{tabular}{|c|c|c|}
\hline THEME & & CATEGORIES RELEVANT TO EACH THEME \\
\hline \multicolumn{2}{|l|}{ Foundational drives of integrity } & $\begin{array}{l}\text { Moral compass } \\
\text { Integrity reflects core values that are universally accepted: } \\
\text { - A people orientation based on respect and empathy } \\
\text { - The will to live a meaningful and purposeful life } \\
\text { - An internal locus of control } \\
\text { - Optimism and enthusiasm } \\
\text { Inner drive }\end{array}$ \\
\hline \multicolumn{2}{|l|}{ Authenticity (intra and interpersonal) } & $\begin{array}{l}\text { Authenticity } \\
\text { Ulterior motives }\end{array}$ \\
\hline \multirow[t]{2}{*}{ Functions of integrity } & Cognitive functions of integrity & $\begin{array}{l}\text { Moral intelligence } \\
\text { Self-insight: } \\
\text { - Self-knowledge } \\
\text { - Self-reflection }\end{array}$ \\
\hline & Affective functions of integrity & $\begin{array}{l}\text { Conscience } \\
\text { Self-regard }\end{array}$ \\
\hline Developmental context of integrity & & $\begin{array}{l}\text { - Parental and other role-models } \\
\text { - Religious context } \\
\text { - Cultural and schooling context } \\
\text { - Disciplined upbringing fostering the development of integrity } \\
\text { - Idiosyncratic life experiences }\end{array}$ \\
\hline Competencies of integrity & & $\begin{array}{l}\text { Self-motivation and drive } \\
\text { Moral courage and assertiveness } \\
\text { Honesty } \\
\text { Consistency } \\
\text { Commitment } \\
\text { Diligence } \\
\text { Self-discipline } \\
\text { Responsibility } \\
\text { Trustworthiness } \\
\text { Fairness }\end{array}$ \\
\hline
\end{tabular}


TABLE 2

Core values that reflect integrity

CORE VALUE
A people orientation based on the principles of respect and
empathy:
The research participants' experiences of people with integrity reflected
that such people have a people orientation based on respect for the
dignity of other people as well as showing care and consideration for other
people's interests and their well-being, in other words empathy.

people's interests and their well-being, in other words empathy.

SOME EVIDENCE FROM THE DATA
"if you have values such as you know you respect the dignity of each individual for me you're a
man of integrity"

"I would say that would be fundamental respect for people ... great respect for people, great respect for human dignity"

"Personal integrity means knowing that your interests are just as important as mine"

"Someone with few skills who actually acts decently towards others"

The will to live a meaningful and purposeful life:

Stories told by the research participants indicated that people with integrity are driven or motivated by a need for meaning and purpose, manifesting in attempts to add value, make a difference or, phrased differently, contribute to something external to the self.
"Integrity has purely to do with one's ultimate purpose in life wanting to making a difference"

"What are you doing, why are you doing it and how can you make sense of and find meaning in the future?"

"there's a big sense of you need to do what's right you need to contribute or there lies happiness in being part of something bigger than yourself"
A disposition to life based on an internal locus of control: general, reflecting a realistic and responsible approach to life, the role that one plays in it and the choices that one makes during it. Such an internal being to whom life happens but that one fulfils an active role in life through the choices that one makes and one's everyday reactions. The research participants related integrity to an attitude towards life in locus of control furthermore reflects the belief that one is not a hopeless

"I've got my own mind I want what I want and I do it and if I have to make certain choices I'll make those choices undoubtedly because I'm assertive in a very gentle way you know I'm not hopeless"

"the sense of knowing that my destiny is in my hands ... you are what you make you know"

"That person will take responsibility for his own life and carry on"

"but there's always something you can give never think you can't give anything you sit back and you must receive because that's a very, very bad life attitude"

"the second thing I look for in this order is attitude positive attitude ... positive attitude to doing things to getting things done to themselves to their fellow human beings to the jobs they've had"

An approach to life facilitated by optimism and enthusiasm: Some research participants felt strongly that integrity is displayed in an optimistic and enthusiastic approach to life. Optimism and enthusiasm pertain to having positive energy (passion) and a positive attitude towards life in general, that is believing in a positive future, that problems can be resolved and that one is never helpless. "l'd like to write a book on how to enjoy life and succeed in an imperfect unfair world"

"who'll be very positive and what's the word I'm trying to find contributory constructive behaviour in a company they'll encourage their fellow workers"

"you should be grateful for any opportunities that come your way you should try to be positive and optimistic and seek the good things in life rather than the bad"

\section{Authenticity}

Apart from relating integrity to a moral compass and an inner drive, the research participants also concurred that living an authentic life in relation to the moral compass and inner drive is fundamental to integrity. In constructing integrity, the interviewees described authenticity as being genuine, straightforward and true to oneself. Having integrity means that "one should be straight-forward in the way you work with others just be yourself". In this regard, one research participant commented on people with integrity as having a sense of "to thine own self be true ${ }^{4 \prime}$. Being authentic seems key to having integrity and seems to be what makes it so difficult to attain true integrity throughout one's life: "It's quite a challenge to be told to be true to yourself it's easier to go with the flow and other people's opinions but in the long run it's a disaster".

From the interviewees' accounts and from existing literature, authenticity seems to manifest on both an intrapersonal and an interpersonal level. On an intrapersonal level, displaying integrity implies being true (or congruent) to one's inner drive and to one's moral principles and considering both these when making decisions. In relation to the inner drive, Peterson and Seligman (2004) note that authenticity is attained when people are able to express their inner commitments, implicit interests and values (Harter, 2002). Integrity also pertains to acting authentically to the moral compass. In this regard, McFall (1987, p. 6) emphasises that integrity can be understood only if one's relationship with one's principles and values is authentic: "A merely conventional relation to one's principles seems to rule out personal integrity".

In conceptualising authenticity from the data, it was revealed that being genuine, straightforward and true to oneself extends to honestly and openly displaying who one is and what one's intentions are on an interpersonal level. This includes not having pretences, hidden agendas or ulterior motives when interacting with others: "I have enormous respect for him because he's not someone with two sets of information" and "I don't want the clients to wonder what game I'm playing it must just be straightforward". The view of integrity expounded by Harter (2002, p. 382) relates to authenticity on an interpersonal level, in other words being honest and truthful in one's actions and interactions as opposed to being, inter alia, "concealing . . charading ... faking, and hiding behind a façade . . . elusive, evasive ... two-faced, manipulative ... deceitful".

\section{Functions of integrity}

The functions of integrity emerged as another core theme that presents a number of categories and explains certain functions in the process of developing integrity and a striving for integrity throughout one's life. These categories were clustered around the subcategories of cognitive and affective functions of integrity.

Cognitive functions of integrity: Moral intelligence and self-insight

The research participants related integrity to distinguishing right from wrong in a particular situation: "Integrity is knowing the difference between right and wrong" and "there's a big sense of you need to do what is right". The ability to know right from wrong is based on the knowledge and understanding of generally accepted norms and principles and of their applicability to and significance in a particular situation (that is, moral knowledge): "People often don't realise that a solution looks easy and that such emotional relief is actually cognitively wrong ethics is a cognitive thing you must think about it's not obvious".

Reflecting on why one should behave in a particular manner and thinking about one's norms and principles and their

This phrase originates from William Shakespeare's Hamlet, which Dean (2004, p. 2) implicitly also links to integrity: "To thine own self be true, and it must follow, as the night the day, thou canst not then be false to any man." 
applicability in a particular situation suggest a cognitive process, which Lickona (2001) refers to as moral reasoning. Lickona (2001) argues that moral reasoning is the cognitive aspect of good character that helps one to understand why it is important to act morally by being able to prioritise one's values. Rust (1999) and Carter (1996) also regard moral reasoning as part of integrity.

Moral intelligence is therefore represented by both moral knowledge and moral reasoning. From the research participants' experiences, it is evident that one should know what is right and wrong and learn this throughout one's life. One should also be able to reflect on and to reason which principles are more important in any particular situation and why this is so.

The cognitive process of comparing and aligning personal and universally accepted values further implies a sense of self-knowledge or self-understanding: "I think integrity really revolves around understanding yourself... I think that if you have integrity you must know yourself this is my capacity this is what I'm good at this is what I'm not good at . . know thyself". A research participant spoke about her own integrity as follows: "Because
I know who I am, I don't need anybody to tell me who I am". Simons (2002) also links self-knowledge to integrity, stating that people can act congruently with their priorities and preferences only if they know what they are.

In the context of integrity, self-insight, however, requires more than mere self-knowledge. It requires cognitively processing its content component (self-knowledge) through self-reflection. In one's striving for integrity, "obviously by that time you start having a lot of self-introspection". Self-reflection is inevitable when striving for integrity despite the fact that it is a difficult process: "Look you need to look at yourself and for many people that's exceptionally scary looking at yourself facing yourself". Self-reflection is also particularly evident in the participants' accounts of their integrity development: "It is something that puts you in touch with yourself like looking inside yourself".

Integrity is the ability to judge and evaluate oneself against universal values and principles, such as respect and empathy and an internal locus of control. Self-reflection is therefore a natural consequence of having integrity because it is a function of integrity to ensure the alignment of one's behaviour with

TABLE 3

Competencies of integrity

\begin{tabular}{|c|}
\hline COMPETENCY AND COMPETENCY DEFINITION \\
\hline $\begin{array}{l}\text { Self-motivation and drive: } \\
\text { An inner drive and energy to set goals and work hard to } \\
\text { achieve them, to fulfil commitments and to maintain or even } \\
\text { exceed standards of performance. }\end{array}$ \\
\hline $\begin{array}{l}\text { Moral courage and assertiveness: } \\
\text { The courage to act on and stand up for what one believes } \\
\text { and to show one's principles and values publicly and voice } \\
\text { them. This includes the courage of self-reflection in the quest } \\
\text { for self-insight. }\end{array}$ \\
\hline $\begin{array}{l}\text { Honesty: } \\
\text { Truthfulness with oneself and others about one's intentions } \\
\text { and capacity. This includes telling the truth and declaring } \\
\text { one's intentions. It manifests in transparent and open } \\
\text { communication and in sharing information proactively. }\end{array}$ \\
\hline $\begin{array}{l}\text { Consistency: } \\
\text { The consistent application of and living according to core } \\
\text { values and principles in all the different areas of one's life } \\
\text { (i.e. work and personal life). }\end{array}$ \\
\hline $\begin{array}{l}\text { Commitment: } \\
\text { Perseverance to attain what one has committed oneself to } \\
\text { doing and to one's duties, responsibilities and obligations, } \\
\text { whether it is a public (commitment to others) or a private } \\
\text { (commitment to oneself) commitment, and despite difficult or } \\
\text { otherwise challenging circumstances. }\end{array}$ \\
\hline $\begin{array}{l}\text { Diligence: } \\
\text { The display of a diligent attitude towards one's work, of } \\
\text { perseverance in one's work effort and of an industrious } \\
\text { character. }\end{array}$ \\
\hline
\end{tabular}

Self-discipline:

Discipline to live according to one's values and principles and to attain what one has set out to do (as expressed in one's inner drive). Discipline to function within the boundaries of one's moral compass, within agreed-upon rules and po one's moral compass, within agreed-upon rules and
princips and within commitments to oneself and others.

\section{Responsibility:}

Responsibility: The acceptance of responsibility for one's goals and
aspirations, for one's limitations and strengths, for the aspirations, for one's limitations and strengths, for the
choices that one makes and for the consequences of one's choices that one makes and for the consequences of one's
actions. The acceptance of responsibility for other people actions. The acceptance of responsibility for other people
or institutions, for their interests and for one's role in one's interrelationships with them.

\section{Trustworthiness:}

The display of a reputation for keeping one's word commitments and responsibilities to the effect that others can trust one to do what one says.

\section{Fairness:}

Fairness, equitability and non-bias in one's decision making, especially in decisions that involve and impact on others.

\section{SOME EVIDENCE FROM THE DATA}

"look I think people who know you know that in terms of delivery there's no doubt about it you're the type of person that will see a thing through"

"a positive attitude to doing things to getting things done... you know a can-do attitude an energetic view of getting things done"

"trust means that somebody is going to stand up for you when things get rough despite being unpleasant so to practise integrity you need balls"

"integrity also meaning having to defend your core values as well if I believe this is an idea or a value that's right you know no matter what would I be given a carrot or would I be threatened or what I'll stand by it"

"there's something that you can pick up if you're looking for it integrity do you tell the truth do you live the truth as opposed to the opposite obviously you can pick up the extreme can I use the word bullshitter"

"to me lack of integrity really goes with dishonesty"

"I think integrity means showing yourself in a similar way or showing similar sides often"

"the story I tell you must be the same every time, not different stories"

"it means this person will be predictable....

"they've impressed me with how they have stuck to their word . . there are other people that I would not touch with a ten-foot bargepole because in every respect they've let me down promises not kept undertakings not kept"

"the type of person who says what is it that you're going to do and act on it . . give me a task and say go and do it I'll find ways even if it means crafting things and doing things in such a way that I can accomplish that goal"

"a person who is work-shy cannot be proud and have integrity"

"everything will not be easy sure it will take hard work"

"it was just I really slogged I wanted it so badly ... I couldn't afford any luxury to be lazy and stuff like that you know I really burnt the candle"

"he is also stricter in terms of his lifestyle more disciplined"

"we all worked extremely hard at our school work farm work and sports activities it had a huge impact on our self-discipline

"so there's control at all times and accountability and nothing has been abused ... for me power goes with responsibility you can't be in a power position and don't have responsibility"

"being a talented person comes with both the responsibility towards yourself to protect and live it out but it also comes with the responsibility to giving something back"

"so for me integrity means ensuring security, security of the organisation's finances, its people and its processes"

"anyway integrity in my mind in a business context really means trust can I trust this person can I trust him to keep an appointment to be punctual to do as they say"

"by having high integrity you ensure that in future you will be trusted . . it is a sense of trust"

"it has to be for everybody else what you apply to yourself must go to everybody else"

"I'll do it fairly as infrequently as possible with the most justice as I can bring out" 
standards within the moral compass (Simons, 2002). Dishonest self-reflection equals rationalising one's behaviour from an underlying selfish motive and an inability to realise what the impact of one's decisions and actions is on others. According to Lickona (2001), the self-awareness of personal needs and expectations is crucial to the balancing of personal needs with external normative responsibility towards others. The development of this ability leads to integrity.

\section{Affective functions of integrity: Conscience and self-regard}

Achieving the ultimate state of integrity seems to be a continuous striving even for those who are regarded as having a character with high integrity. In this striving for integrity, the research participants pointed to their conscience and self-regard as prominent affective components that guide their decisions and actions. These affective functions of integrity may be linked to the second fundamental element of good character as presented by Lickona (2001), namely a moral feeling.

The conscience contains an evaluative function that judges one's behaviour against the moral compass, with consequent negative feelings if one's behaviour does not reflect integrity: "That feeling of dishonesty stayed with me for many years ... the fact that I remembered it today means that I actually feel quite bad about $i t^{\prime \prime}$ and "There are some things I did that I'm ashamed of that will stay with me forever". "You know to have a conscience and to do good and be good in whatever I do and to be extremely principled" is an integral part of one's integrity. One's conscience, however, is not only a post-evaluator of one's behaviour; it is also a proactive evaluator or motivator in the sense that it sets certain standards that one wishes to live up to: "I would always want to say to myself if I do this my conscience just wouldn't allow me".

From the data, it became evident that, apart from linking integrity to conscience, integrity also relates to an affective function of the self, in other words self-regard. In relation to integrity, self-regard means a rational and positive sense of self. It incorporates being comfortable with whom one is as a result of perceived strengths and despite perceived limitations: "In knowing yourself in knowing not just what you can do but also knowing what you can't do and be almost sort of comfortable with that comfortable to expose that and acknowledge that".

A number of research participants used examples of people who portray a poor sense of self as people with limited integrity. Specifically, a poor sense of self is based either on over-inflated self-esteem or on feelings of inferiority. Over-inflated selfesteem results in an exaggeration of one's strengths, knowledge and capabilities. A poor sense of self may result in people holding up false pretences to impress others: "If they're good at everything and know everything then you've got a problem" and "I think he came across a bit too good to be true yes he's a smooth talker you know and it seems something in me said this is too good to be true".

\section{Competencies of integrity}

In their narratives about people with integrity, the research participants often described behaviour that either reflected integrity or did not. Various categories thus emerged from the data pertaining to different and related behaviours that describe integrity. Eight categories emerged from the data that were clustered together to form competencies of integrity. These categories reflected behaviours that may be regarded as consequent behavioural manifestations of integrity. They are explicated in Table 3 as they are grounded in the data.

\section{Development context of integrity}

On probing the development of integrity, it became evident that, on the one hand, the research participants' integrity development was strongly rooted in their upbringing. On the other hand, the narratives from the data provided evidence that the research participants' integrity never seized to develop. Integrity thus appears to be shaped in the context of the research participants' upbringing ("integrity starts with the way in which I was raised") and in a variety of situations that permeated their adult lives.

In essence, integrity has a developmental and relative nature because it is formed and shaped throughout one's life and is contextually determined: "How integrity manifests depends on that environment ... whereas in another environment it will differ . . from environment to environment or situation to situation". The developmental context of integrity also speaks to its relative nature, emphasising the point that integrity is developed and formed relative to one's context: "Moral values and integrity are relative ... if you're starving and your family is starving and there's potatoes in the field next door with nobody watching and you steal those potatoes I don't know if that's integrity or not but that's still stealing...".

In an effort to describe the developmental context of integrity, several categories came to the fore that presented the type of context or upbringing that influences integrity development:

- Integrity development is related primarily to parental role-models but is also shaped by significant others.

- Integrity development is grounded in the context of one's religion.

- Integrity development is incumbent upon normative influences from one's cultural and educational context.

- Integrity development is fostered by a disciplined upbringing.

- Integrity development is impacted on by idiosyncratic life experiences.

\section{DISCUSSION}

\section{Interpretation}

The objective of this research was to construct an understanding of integrity by developing a conceptual framework integrating the related constructs of integrity. Miles and Huberman (1994) regard building a conceptual framework as part of the theory-building process in qualitative research and describe a conceptual framework as an articulation and presentation of the categories and their interrelationships that explain the phenomenon being studied. An analysis of the interrelationships between the core themes and their related categories presented above resulted in a conceptual framework of integrity and integrity development, which is presented in Figure 1.

From the results, it follows that people with a high integrity can be described as people who have and live according to a core set of moral principles, of which at least some can be said to be more or less universally accepted as a minimum standard for high integrity. Having such a moral compass determines people's propensity to stand firm on their values, beliefs and principles. Internalising integrity-related values, such as respect and empathy for others, the will to live a purposeful and meaningful life, an internal locus of control and an optimistic and enthusiastic life approach, all seem to be a prerequisite for a moral compass foundational to behaviour with integrity.

The extent of one's integrity is, however, also determined by one's inner wants, needs, aspirations and goals, as contained in the inner drive. The relationship between integrity and inner drive initially seemed positive in the sense that strong integrity was related to being internally motivated and to living congruently with one's inner wants, needs, aspirations and goals. The inner drive, however, also acts as a potential threat to integrity because personal wants, needs and aspirations may tempt one to act from pure self-interest. A poor sense of integrity is related to acting in self-interest, especially when it is 


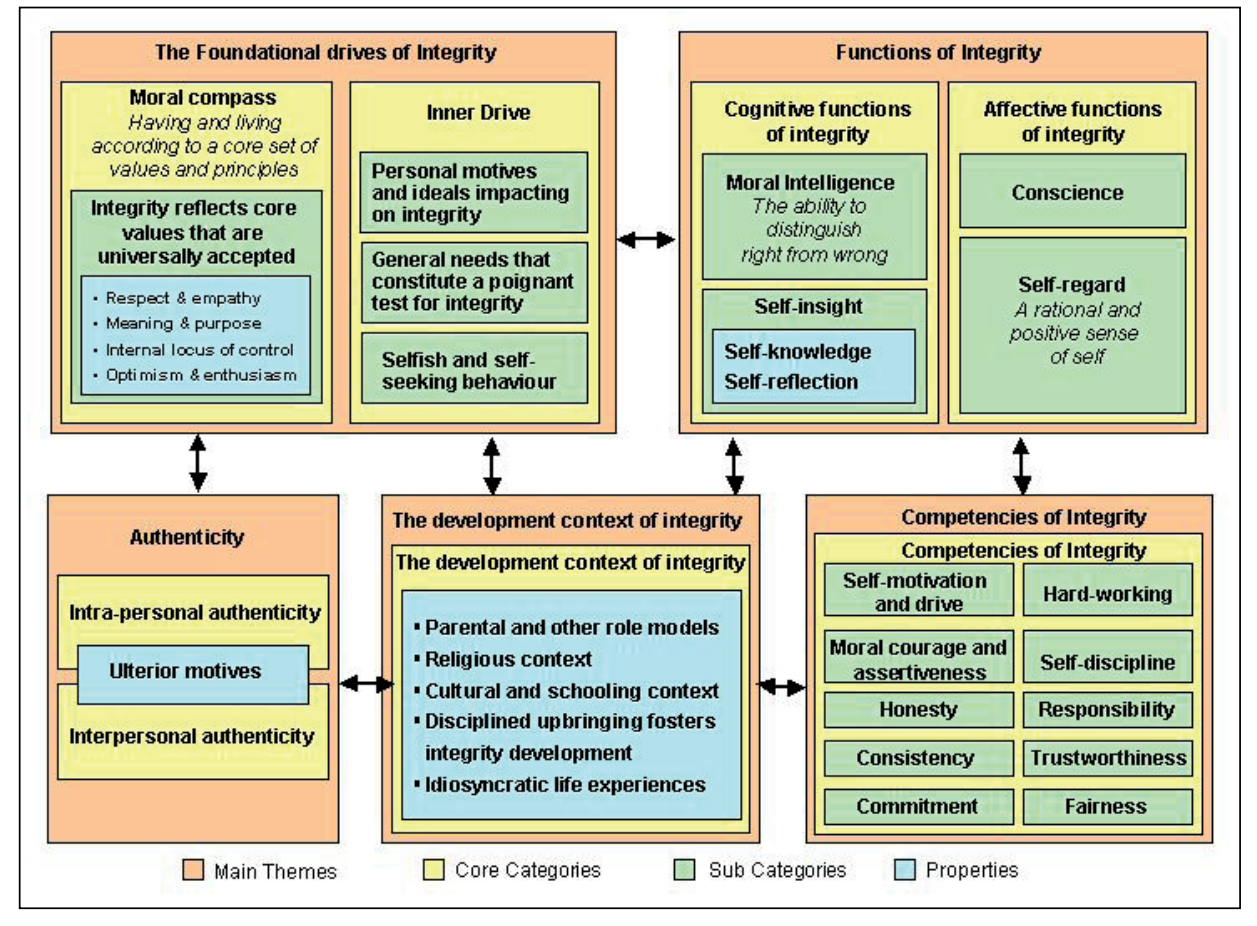

FIGURE 1

Conceptual framework of integrity and integrity development

at the cost of others, or, more specifically, at the cost of integrityrelated values within the moral compass.

Living in congruence with one's inner drive clearly relates to being authentic, another prerequisite of integrity that was identified. A dynamic irony is evident in relating a sense of high integrity with being authentic yet poor integrity with behaviour motivated by self-interest because one cannot be regarded as being authentic if one does not act according to one's inner wants and needs. Integrity is therefore driven by one's inner drive as well as by one's moral compass and, to live with integrity, one should be authentic with regard to both these foundational drives. Despite being equally significant, however, there is a potentially conflicting dynamic between the foundational drives of integrity that makes living authentically and with integrity a challenging experience. Being driven to act from the moral compass may, for example, constitute more altruistic and other-focused behaviour at the cost of one's inner drive. Seen from a different perspective, being driven to act from one's inner drive may constitute more self-centred behaviour. It seems that, to achieve integrity, one needs to attain a certain balance in living authentically in relation to the moral compass and inner drive.

From the results, integrity was also related to particular cognitive and affective functioning components. It is proposed that the functions of integrity facilitate a person's ability to balance the foundational drives of integrity (in other words the moral compass and inner drive) and thus the ability to function with either more or less integrity. It is therefore proposed that moral intelligence and self-insight as well as self-regard and a sensitive conscience facilitate integrity-related behaviour.

The development of integrity is rooted mainly in one's upbringing, through which parental and other significant role-models within a particular sociocultural context shape the moral compass, inner drive and moral intelligence, selfinsight, conscience and self-regard. From the developmental context of integrity, integrity should be regarded as an evolving trait that is developed and influenced by various contextual circumstances that range from childhood until death. Such a relative and contextual perspective on integrity, however, defines it as not being an absolute construct. It would therefore seem that, although one may have integrity, one is continually bombarded with experiences and choices in life that tax one's ability to retain one's integrity. In each new environment, work context and unique situation, people display behaviour that reflects their level of integrity. It is therefore possible that a person with high integrity may, in a particular situation, act with limited integrity and vice versa. Integrity may ultimately be an evolving construct but people's integrity is judged by their day-to-day behaviour.

Various behaviours portray integrity. These have been called "competencies of integrity". The competencies of integrity can be regarded as the behavioural consequences of living authentically in relation to one's moral compass and one's inner drive. These behaviours are furthermore facilitated by being morally intelligent, having self-insight and a positive and rational self-regard as well as being directed by one's conscience in relation to the moral compass.

From the research participants' constructions of integrity, various seemingly anomalous themes emerged that also reflect one of the core philosophical debates on the conceptualisation of integrity, which is integrity as moral responsibility versus integrity as authenticity (McFall, 1987). It was initially relatively confusing and challenging to distinguish between seemingly opposing categories (such as living in congruence with both one's moral compass and one's inner drive), while simultaneously attempting to integrate these anomalies in the conceptualisation of integrity. In attempts to integrate these categories, it becameevident that integrity can be conceptualised only when there is an understanding of the dynamic constructs underlying integrity that combine and interact in different ways in different situations.

\section{Limitations}

As suggested by Locke (2001), a qualitative, grounded-theory study is context-specific, which limits the generalisability of findings (Guba \& Lincoln, 1999). Yet, in qualitative research, the transferability of findings to similar contexts is possible 
(Leininger, 1994; Mertens \& McLaughlin, 2004) and is enhanced through a thorough explication of the research paradigm and methodology (Schofield, 2002) and the use of a particular analytical methodology, such as grounded theory (Silverman, 2000). The credibility of findings has also been a predominant criticism against qualitative research. Credibility in this study was therefore addressed through member checking, peer reviews and rigorous descriptions of the raw data that support the interpretations made (Leininger, 1994; Marshall \& Rossman 1995; Rubin \& Rubin, 1995).

\section{Recommendations}

The findings of this research provide a sound basis for the development of a substantive theory (cf. Locke, 2001 regarding the objective of grounded-theory study) on integrity in the South African work context. It may also provide a foundation for the refinement or further development of integrity tests. Further research may be initiated with regard to confirming the proposed conceptual framework in different business contexts and through the study of negative cases (Pidgeon \& Henwood, 1997). Integrity in this research was studied from an individual perspective. A systems perspective may therefore yield additional significant data explaining situational and organisational factors that interact with individual integrity constructs to determine behaviour with integrity in various work contexts.

\section{Conclusion}

The conceptualisation of integrity through the conceptual framework that was developed in this research makes a decided theoretical contribution to the field of industrial and organisational psychology and may have significant implications for human-relations management policy and practice. Understanding behaviour with integrity in the work context provides a sound theoretical basis for the development of psychological tools and interventions that are aimed at enhancing integrity in an organisational context. The conceptual framework provides a basis for the development of assessment products and training and of development interventions that enhance employee integrity in the work environment. The research furthermore adds to the evolving use of qualitativeresearch methodology in the field of industrial psychology, specifically in the South African context and with regard to using an interpretive grounded-theory methodology.

\section{REFERENCES}

Barrett, P. (2003). Beyond psychometrics: Measurement, nonquantitative structure, and applied numerics. Journal of Managerial Psychology, 18(5), 421-439.

Becker, T.E. (1998). Integrity in organisations: Beyond honesty and conscientiousness. Academy of Management Review, 23(1), 154-161.

Beebe, J. (1992). Integrity in depth. Houston, TX: Texas A\&M University Press.

Bryman, A \& Burgess, R.G. (1999). Qualitative research, volume 1. London: Sage.

Burleson, B. (2001). Pathways to integrity: Ethics and psychological type. Gainesville, FL:Centre for Applications of Psychological Type.

Camara, W.J. \& Schneider, D.L. (1994). Integrity tests: Facts and unresolved issues. American Psychologist, 49(2), 112-119.

Cameron, K.S. (2003). Organisational virtuousness and performance. In J.E. Dutton \& R.E. Quinn (Eds.), Positive organisational scholarship: Foundations of a new discipline. San Francisco: Berrett-Koehler.

Camic, P.M., Rhodes, J.E. \& Yardley, L. (2003). Naming the stars: Integrating qualitative methods into psychological research. In P.M. Camic, J.E. Rhodes \& L. Yardley (Eds.), Qualitative research in psychology: Expanding perspectives in methodology and design. Washington: APA.
Carter, S.L. (1996). Integrity. New York, NY: HarperPerennial.

Charmaz, K. (2000). Grounded theory: Objectivist and constructivist methods. In N. Denzin \& Y. Lincoln (Eds.) Handbook of qualitative research (2nd Ed.). Thousand Oaks, CA: Sage.

Charmaz, K. (2003). Qualitative interviewing and grounded theory analysis. In J.A. Holstein \& J.F. Gubrium (Eds.), Inside interviewing, new lenses, new concerns. Thousand Oaks, CA: Sage.

Coffey, A., Holbrook, B. \& Atkinson, P. (1999). Qualitative data analysis: Technologies and representations. In A. Bryman \& R.G. Burgess (Eds.), Qualitative research, volume 3. London: Sage.

Cox, D., Lacaze, M. \& Levine, M.P. (1999). Should we strive for integrity? The Journal of Value Inquiry, 33(4), 519-530.

Craig, S.B. \& Gustafson, S.B. (1998). Perceived leader integrity scale: An instrument for assessing employee perceptions of integrity. Leadership Quarterly, 9(2), 127-145.

Crotty, M. (2005). The foundations of social research: Meaning and perspective in the research process. London: Sage.

Cullen, M.J. \& Sackett, P. (2004). Integrity testing in the workplace. In J.C. Thomace (Ed.), The comprehensive handbook of psychological testing, volume 4. Hoboken, NJ: Wiley.

Dean, B. (2004). Integrity. Authentic happiness coaching e-newsletter, 2(23). Retrieved October 21, 2004, from the World Wide Web: http://www.authentichappinesscoaching.com

Denzin, N.K. \& Lincoln, Y.S. (Eds.) (1994). Handbook of qualitative research. Thousand Oaks, CA: Sage.

Denzin, N.K. \& Lincoln, Y.S. (Eds.) (2000). Handbook of qualitative research (2nd Ed.). Thousand Oaks, CA: Sage.

Dey, I. (1999). Grounding grounded theory: Guidelines for qualitative inquiry. Boston, MA: Academic Press.

Durrheim, K. (2004). Research design. In M. Terre Blanche \& K. Durrheim (Eds.), Research in practice: Applied methods for the social sciences. Cape Town: UCT Press.

Easton, L., McComish, J.F. \& Greenberg, R. (2000). Avoiding pitfalls in qualitative data collection and transcription. Qualitative Health Research, 10(5), 703-707.

Fontana, A. \& Frey, J.H. (1994). Interviewing: The art of science. In N.K. Denzin \& Y.S. Lincoln (Eds.), Handbook of qualitative research. Thousand Oaks, CA: Sage.

Furnham, A. \& Taylor, J. (2004). The dark side of behaviour at work: Understanding and avoiding employees leaving, thieving and deceiving. New York: Palgrave MacMillan.

Glaser, B. \& Strauss, A. (1967). The discovery of grounded theory. Chicago: Aldine.

Guba, E.G. \& Lincoln, Y.S. (1999). Competing paradigms in qualitative research. In N.K. Denzin \& Y.S. Lincoln (Eds.) The landscape of qualitative research, theories and issues. Thousand Oaks, CA: Sage.

Harkess, S.H. \& Warren, C.B. (1993). The social relations of intensive interviewing, constellations of strangeness and science. Sociological Methods and Research, 21(3), 317-339.

Harter, S. (2002). Authenticity. In C.R. Snyder \& S.J. Lopez (Eds.), Handbook of positive psychology. New York: Oxford.

Henning, E., Van Rensburg, W. \& Smit, B. (2004). Finding your way in qualitative research. Pretoria: Van Schaik.

Hertz, R. \& Imber, J.B. (1995). Studying elites using qualitative methods. Thousand Oaks, CA: Sage.

Hogan, J. \& Ones, D. (1997). Conscientiousness and integrity at work. In R. Hogan \& J. Johnson (Eds.), Handbook of personality psychology. San Diego: Academic Press.

Josselson, R. (2000). Relationship as a path to integrity, wisdom and meaning. In P. Young-Eisendrath \& M.E. Miller (Eds.), The psychology of mature spirituality: Integrity, wisdom, transcendence. London: Routledge.

Kelly, K. (2004). Hermeneutics in action: Empathy and interpretation in qualitative research. In M. Terre Blanche \& K. Durrheim (Eds.), Research in practice: Applied methods for the social sciences. Cape Town: UCT Press.

Kvale, S. (1996). Interviews: An introduction to qualitative research interviewing. Thousand Oaks, CA: Sage. 
Lapadat, J.C. \& Lindsay, A.C. (1999). Transcription in research and practice: From standardisation of technique to interpretive positionings. Qualitative Inquiry, 5(1), 64-86.

Leininger, M. (1994). Evaluation criteria and critique of qualitative research studies. In J.M. Morse (Ed.), Critical issues in qualitative research methods. Thousand Oaks, CA: Sage.

Lennick, D. \& Kiel, F. (2005). Moral intelligence. Upper Saddle River, NJ: Wharton School.

Lickona, T. (2001). What is good character? [26 paragraphs]. Reclaiming children and youth, 9(4). Retrieved May 2, 2003, from the World Wide Web: http://www.proquest.umi.com/ pqdweb?index

Locke, E.A. \& Becker, T.E. (1998). Rebuttal to a subjectivist critique of and objectivist approach to integrity in organisations. Academy of Management Review, 23(1), 170-175.

Locke, K. (2001). Grounded theory in management research. Thousand Oaks, CA: Sage.

Maree, A., Joubert, S.J. \& Prinsloo, J.H. (1996). Die begrondingsteorie as navorsingsmetode. Acta Criminologica, 9(2), 47-54.

Marshall, C. \& Rossman, G.B. (1995). Designing qualitative research (2nd Ed.). Thousand Oaks, CA: Sage.

Mason, M. (2000). Values in multicultural education: Who's ethics? In M. Leicester, C. Modgil \& S. Modgil (Eds.), Education, culture and values (Vol. VI: Moral education and pluralism). London: Falmer Press.

Mason, M. (2001). The ethics of integrity: Educational values beyond postmodern ethics. Journal of Philosophy of Education, 53(1), 47-69.

McFall, L. (1987). Integrity. Ethics, 98(1), 5-20.

Mertens, D.M. \& McLaughlin, J.A. (2004). Research and evaluation methods in special education. Thousand Oaks, CA: Corwin Press.

Miles, M.B. \& Huberman, A.M. (1994). Qualitative data analysis (2nd Ed.). Thousand Oaks, CA: Sage.

Mills, J., Bonner, A. \& Francis, K. (2006). The development of constructivist grounded theory. International Journal of Qualitative Methods, 5(1).

Mouton, J. (2002). Understanding social research. Pretoria: Van Schaik.

Mouton, J. \& Marais, H.C. (1996). Basic concepts in the methodology of the social sciences. Pretoria: HSRC.

Muhr, T. (1997). ATLAS.ti - Visual qualitative data analysis management model building in education, research and business: Short user's manual. Berlin: Scientific Software Development.

Murphy, K.R. (2000). What constructs underlie measures of honesty or integrity? In D.N. Jackson, R.D. Goffin \& E. Helmes (Eds.), Problems and solutions in human assessment. London: Kluwer.

Olsen, L.M. (2002). The relationship between moral integrity, psychological well-being and anxiety. Retrieved August 23, 2006, from the World Wide Web: http://www.charis.wlc. edu/publications/charis-spring02/olson.pdf

Ones, D.S. (1993). The construct validity of integrity tests. Unpublished D dissertation, Iowa: University of Iowa City.

Ones, D.S. \& Viswesvaran, C. (2001). Integrity tests and other criterion-focussed occupational personality scales (COPS) used in personnel selection. International Journal of Selection and Assessment, 9, 31-39.

Ones, D.S., Viswesvaran, C. \& Schmidt, F.L. (1993). Comprehensive meta-analysis of integrity test validities: Findings and implications for personnel selection and theories of job performance. Journal of Applied Psychology. 78(4), 679-703

Ostrander, S.A. (1995). Surely you're not in this just to be helpful: Access, rapport, and interviews in three studies of elites. In R. Hertz \& J.B. Imber (Eds.), Studying elites using qualitative methods. Thousand Oaks, CA: Sage.
Park, N. \& Peterson, C.M. (2003). Virtues and organisations. In J.E. Dutton \& R.E. Quinn (Eds.), Positive organisational scholarship: Foundations of a new discipline. San Francisco: Berrett-Koehler.

Peterson, C. \& Seligman, M.E.P. (2004). Character strengths and virtues: A handbook and classification. New York. Oxford.

Petrick, J.A. \& Quinn, J.F. (1997). Management ethics: Integrity at work. London: Sage.

Pidgeon, N. \& Henwood, K. (1997). Using grounded theory in psychological research. In N. Hayes (Ed.), Doing qualitative analysis in psychology. Sussex: Psychology Press.

Plummer, K. (2001). Documents of life 2: An invitation to critical humanism. London: Sage.

Potter, J. \& Hepburn, A. (2005). Qualitative interviews in psychology: Problems and possibilities. Qualitative Research in Psychology, 2(4), 281-307.

Putman, D. (1996, June). Integrity and moral development. The Journal of Value Inquiry, 30, 237-246.

Rieke, M.L. \& Guastello, S.J. (1995). Unresolved issues in honesty and integrity testing. American Psychologist, 50, 458-459.

Rosen, D.H. \& Crouse, E.M. (2000). The Tao of wisdom. In P. Young-Eisendrath \& M.E. Miller (Eds.), The psychology of mature spirituality. Integrity, wisdom, transcendence. London: Routledge.

Rubin, H.J. \& Rubin, I.S. (1995). Qualitative interviewing: The art of hearing data. Thousand Oaks, CA: Sage.

Rust, J. (1999). The validity of the Giotto integrity test. Personality and Individual Differences, 27, 755-768.

Schabracq, M.J. (2003). Everyday well-being and stress in work and organisations. In M.J. Schabracq, J.A.M. Winnubst \& C.L. Cooper (Eds.), The handbook of work and health psychology. Chichester: Wiley.

Schauber, N. (1996). Integrity, commitment and the concept of a person. American Philosophical Quarterly, 33(1), 119-129.

Schofield, J.W. (2002). Increasing the generalisability of qualitative research. In A.M. Huberman \& M.B. Miles (Eds.), The qualitative researcher's companion. Thousand Oaks, CA: Sage.

Silverman, D. (2000). Doing qualitative research: A practical handbook. London: Sage.

Simons, T. (2002). Behavioural integrity: The perceived alignment between managers' words and deeds as a research focus. Organization Science, 13(1), 18-37.

Smit, B. (2005). Computer assisted qualitative data software: Friend or foe. South African Computer Journal, 214(35), 107-111.

Snape, D. \& Spencer, L. (2004). The foundations of qualitative research. In J. Ritchie \& J. Lewis (Eds.), Qualitative research practice: A guide for social science students and researchers. London: Sage.

Strauss, A. \& Corbin, J. (1990). Basics of qualitative research: Grounded theory procedures and techniques. Newbury Park, CA: Sage.

Suddaby, R. (2006). From the editors: What grounded theory is not. Academy of Management Journal, 49(4), 633-642.

Terre Blanche, M. \& Kelly, K. (2004). Interpretive methods. In M. Terre Blanche \& K. Durrheim (Eds.), Research in practice: Applied methods for the social sciences. Cape Town: UCT Press.

Thomas, R.J. (1995). Interviewing important people in big companies. In R. Hertz \& J.B. Imber (Eds.), Studying elites using qualitative methods. Thousand Oaks, CA: Sage.

Warren, R. (2002). The purpose driven life. Michigan: Zondervan.

Wolfinger, N.H. (2002). On writing fieldnotes: Collection strategies and background expectancies. Qualitative Research, 2(1), 85-95.

Yin, R.K. (2003). Applications of case study research (2nd Ed.). Thousand Oaks, CA: Sage.

Young-Eisendrath, P. \& Miller, M.E. (Eds.) (2000). The psychology of mature spirituality: Integrity, wisdom, transcendence. London: Routledge. 